\title{
Da evolução histórica do marketing político na propaganda eleitoral no Brasil ao sucesso das campanhas presidenciais.
}

(From the historical evolution of political marketing in electoral propaganda in Brazil to the success of the presidential campaigns.)

\section{Márcio Felipe da Rocha e Silva \\ Diretor de Comunicação e Marketing na ABRAZ, Professor na FAMEP.}

Fecha recepción: 21-10-2017

Páginas 92-106

Fecha aceptación: 01-12-2017

\section{Resumo.}

Este artigo buscou uma reflexão sobre o marketing político desde a evolução histórica, as estratégias da propaganda utilizadas pelos responsáveis, o trabalho das campanhas políticas por meio de exemplos, a retrospectiva do marketing político e o registro de campanhas bem sucedidas com exposições detalhadas sobre a temática, partindo de autores e especialistas da área. A pesquisa consolidou 0 trabalho em análise de material bibliográfico do tipo descritivo, descrevendo os inúmeros aspectos, dentre eles, como os políticos arquitetam a conquista dos votos do povo. Uma panorâmica das estratégias usadas, principalmente na propaganda eleitoral. Contudo, a pesquisa mostra que 0 marketing pode elevar uma campanha política ao sucesso e, ou contribuir para a efetivação de mudanças de comportamento do eleitorado desde que os candidatos a cargos eletivos apostem numa propaganda bem planejadas.

Palavras-chave: marketing; política; propaganda; campanha; eleitoral

\begin{abstract}
.
This article has sought to reflect on political marketing since the historical evolution, the strategies of advertising used by those responsible, the work of political campaigns through examples, the retrospective of political marketing and the registration of successful campaigns with detailed expositions on the subject , starting with authors and specialists of the area. The research consolidated the work in analysis of bibliographic material of the descriptive type, describing the innumerable aspects, among them, how the politicians architect the conquest of the votes of the people. An overview of the strategies used, especially in electoral propaganda. However, research shows that marketing can elevate a political campaign to success and, or contribute to, shifting behavior of the electorate as long as candidates for elected office engage in well-planned advertising.
\end{abstract}

Keywords: marketing; policy; advertising; campaign; electoral 


\section{1.-Introdução.}

Com esse trabalho pretende-se apresentar através de pesquisa bibliográfica, a produção de alguns autores e profissionais consagrados do marketing eleitoral e da propaganda política. Assim sendo, procurou-se analisar essas contribuições, dando sentido ao estudo do tema como relevante para o desenvolvimento da comunicação e do trabalho específico ligado a área política e eleitoral.

A pesquisa abordou 0 âmbito da propaganda e do marketing político nas campanhas eleitorais 0 trabalho consiste, primeiramente, em compreender sistemicamente diversos fatores, observando tendências, valores e necessidades impostas pelo mercado analisando cientificamente o comportamento entre eleitor $\mathrm{e}$ candidato a cargos políicos, no âmbito do poder público. Com a globalização, ampliou-se às exigências de forças econômicas e tecnológicas cada vez mais competitivas, onde a palavra "sucesso" tem um significado muito importante, principalmente para o mundo político.

Deste modo, elencou-se alguns questionamentos: Qual a função e 0 uso do marketing político, as principais estratégias da propaganda? As propagandas podem levar uma campanha ao sucesso? Quais os possiveis caminhos e soluções para um marketing de sucesso?

Assim, o objetivo buscou analisar como se dá a conquista do voto e como os políticos orquestram a conquista desses ao pleito eletivo. Ainda, descreve-se uma panorâmica das estratégias usadas, principalmente na propaganda eleitoral gratuita através de exemplos; pontua-se os aspectos históricos e contemporâneos do marketing político no Brasil e no mundo e como o marketing político pode elevar o candidato a uma campanha de sucesso.

A justificativa se dá a partir do momento que se coloca ao marketing político a necessidades de um planejamento sistêmico assentado em um fortalecimento da imagem do político e suas realizações, com vistas a uma carreira, uma estratégia em progressão. Todo o aparato do marketing é usado em torno de uma imagem criada, produzida, alimentada através de ações estratégicas para resultados futuros.

Ainda, entre marketing político e marketing eleitoral, mesmo com singularidades sobre "o Marketing eleitoral", Silva (2002) estabelece muitas diferenças.

- O 'marketing político' está relacionado com a informação da imagem em longo prazo.

- Já o 'marketing eleitoral' é de curto prazo.

Ou seja, as estratégias e a tática definidas são criadas em cima de um ambiente vivo, já existente, em andamento e não de um ambiente criado (Silva, 2002, p.93).

Além, de todos esses aspectos não se pode deixar de destacar, que o marketing político estuda o comportamento sócio-político do ambiente. E, por isso, analisa 
sistematicamente ideias e convicções do eleitorado. Numa definição mais genérica e descritiva, chamamos isso de ideologia. Quando defendidas em grupo, essas ideias tendem a se fortalecerem e podem ser analisadas como um conjunto de crenças, doutrinas e modos de pensar. Enfim, analisar o perfil desse eleitor e seu comportamento através das pesquisas de mercado.

Mattiello e Ribeiro (2006) ressaltam que o marketing é uma poderosa palavra, que está no imaginário social, construída sob discurso e significados, sendo percebidos de muitas formas, produzidas por administradores, publicitários, professores e jornalistas. Percebe-se que o marketing político é uma forma especial de usar a comunicação a favor do candidato, se apropriando dos discursos e significados, integrando-os com "verdades e certezas" que estão no imaginário coletivo, do qual faz parte 0 eleitorado, procurando estabelecer uma ponte entre as necessidades e anseios da sociedade e as pretensões eleitorais e políticas do candidato a gestor. Essa linha tênue terá que ser traçada com a assessoria cuidadosa de um especialista em marketing político, que tenha sensibilidade e meios para exprimir através da propaganda, estabelecendo uma sintonia e empatia com os possíveis eleitores.

Kotler (1978) afirma que o conceito de marketing é aplicável a uma série de organizações e instituições, inclusive, não comerciais. Para ele, diversas áreas específicas podem se aproveitar da unidade do marketing para fazer valer seus conceitos e ideologias, como por exemplo, o marketing social, que é voltado às instituições que visam apenas uma causa ou ideia social.

\section{2.-A evolução histórica do marketing político.}

Um dos primeiros tratados sobre estratégias voltadas para a ação política está no livro 'O Príncipe', Nicolau Maquiavel. Nesta obra o autor adéqua à base política do governo da época e aplica algumas noções básicas de estratégia para um governante, elevando seus escritos a um verdadeiro tratado político. Esta constatação tem destaque no livro "El Marketing Político Conceptos y Estratégias", Beranger (2006, p.16).

De acordo com os preceitos maquiavélicos vale uma reflexão: "Os fins justificam os meios" ou "determinam esses meios"? Essa polêmica tornou Maquiavel mal interpretado durante séculos. $\mathrm{O}$ que Maquiavel quis dizer na verdade é que "(...) os fins determinam os meios e de acordo com seus objetivos você pode traçar seus planos e definir como quer atingi-los".

0 sistema eleitoral norte-americano e 0 europeu são fundamentalmente diferentes do nosso que não há nada que um brasileiro possa fazer, a não ser admirar a perfeição técnica das campanhas ianques e abismar-se diante das quantias astronômicas que nelas se gastam [...]. Desta vez, o homem do marketing brasileiro não pode adaptar nada dos EUA, Alemanha Ocidental ou Japão. 0 marketing político brasileiro se encontra diante de uma situação única e todos 
podem esperar muito mais imprevistos que certezas. $\mathrm{E}$, por isso mesmo, o nosso marketing político irá firmar-se como know-how nacional numa situação essencialmente brasileira (Beranger,2006, p. 17).

Romanini (2006) descreve as estratégias usadas na campanha de Prudente de Morais. O candidato viajava em trens, lombo de burros e possuía uma caderneta de endereços com os nomes dos principais interlocutores, a quem pedia "voto e dinheiro para a sua campanha eleitoral". Apesar de não ser marketing político, as práticas de Prudente de Morais já possuíam umas características do marketing, como por exemplo, a manipulação de sua imagem e a consequente atração de eleitores.

Durante o Estado Novo (1937-1945), Getúlio Vargas (conhecido como "pai dos pobres"), utilizou como principal recurso à comunicação oral e pessoal. 0 rádio, a imprensa, o cinema foram os recursos de divulgação mais utilizados em seu favor que apontava para um Estado forte e seu líder, conhecido como o pai dos pobres, adquiriu um caráter mítico de líder nacional. Suas fotos (símbolos de sua presença constante) estavam presentes nas repartições públicas e foram importantes para difundir sua ideologia (Amaral, 2006, p.145).

Considerado o símbolo de modernidade em sua época, Juscelino Kubitschek (1956- 1961), era um homem popular, carismático, exímio articulador e muito bem assessorado em termos profissionais. Cartazes, panfletos, santinhos, fotos e outras peças publicitárias importantes davam o tom final de um candidato detalhista e meticuloso. Porém, um dos pontos considerados mais importantes para a desenvoltura de JK era a presença constante nos veículos de massa. Seu slogan de campanha foi "50 anos em 50 dias".

Em 1961, Jânio Quadros ocupou a Presidência da República do Brasil. Para ele, 0 rádio era um dos seus principais aliados para ampliar sua popularidade. Grossi (2006) confirma esse modelo de aproximação com o popular, apoiado em pequenos meios e imagens midiáticas simples e cotidianas, quando afirma: (...) que ele soube falar diretamente ao coração dos eleitores. Nas ruas, além do corpoa-corpo, usou santinhos, cartazes e manifestos. O grande símbolo de sua campanha foi a vassoura e ela foi usada em todos os materiais impressos de sua campanha. Objeto popular que representava limpeza na política do País (Grossi, 2006, p.186).

Durante o regime militar (1964-1985), segundo Barel (2007, p.5), os militares usaram muito a mídia para difundir as suas ideologias, por meio da Assessoria Especial de Relações Públicas (AERP). Suas ideias chegavam aos lares brasileiros principalmente através da televisão. Jornais, revistas e o rádio também foram usados, porém, em menor escala. $O$ arquiteto das propagandas políticas do Regime Militar foi o Coronel Octávio Costa. Seus trabalhos eram bastante sutis revela 0 autor. 
Com o retorno da ordem democrática, através da constituição de 1988, José Sarney, assume a presidência da República em Março de 1985, cumprindo um mandato até março de 1990. Este governo enfrenta dificuldades devido ao grande arrocho econômico, inflação em alta, que diminuiu o poder de compra da população, gerando grande descontentamento na classe média. No final do mandato, com índices de popularidade em baixa é eleito seu sucessor, o presidente Fernando Collor de Mello (1990 -1992), primeiro governo civil brasileiro eleito pelo voto direto desde 1960, com plena liberdade partidária e eleição em dois turnos.

Collor contava com a aceitação e apoio da grande mídia, em especial da Rede Globo, que 0 apresentava como um moralista, 'caçador de marajás', super atleta, moderno e homem culto. Seus discursos políticos tinham como promessa a moralização da política e o fim da inflação. Collor foi responsável pela implantação do profissional do marketing eleitoral/político em eleições presidenciais no Brasil. Fernando Collor de Mello apresentou uma campanha inovadora, criativa, com grande apelo midiático, com o objetivo de comunicar melhor com seu público e ampliar sua popularidade.

Meyer e Meyer coloca que "O marketing políico: 0 caso da campanha presidencial de Fernando Collor de Mello", o sucesso da campanha do candidato Collor se fundamentou no modelo desenvolvido por Gross, Newman e Sheth (1991), que se baseia em uma premissa fundamental de que as escolhas de consumo são um fenômeno multidimensional envolvendo múltiplos valores. Os autores identificaram cinco. São eles: o valor funcional, o social, o emocional, o epistêmico e o valor condicional. Ou seja, Fernando Collor era um ótimo produto eleitoral, pois para os profissionais do marketing, ele tinha todos os requisitos necessários. Que requisitos eram esses? A juventude, a boa aparência, a inteligência e uma boa oratória.

Fernando Collor entrou para a história também quando pela primeira vez explorou a tecnologia e os efeitos especiais na televisão que tiveram reflexos positivos na qualidade da imagem dos programas produzidos. Após sucessivos planos econômicos sem sucesso e recessão no País, Collor foi acusado de malversação do dinheiro público e de favorecer ilicitamente seus familiares. A população decepcionada, insuflada pela elite insatisfeita, (a mesma que o pôs para governar 0 País), revoltada com os rumos do governo aumenta o descrédito às ações do governo, o que culminou com o 'impeacheament' de Fernando Collor, do antes famoso "caçador de marajás".

E a pergunta que todo estrategista político faz era: como encontrar uma pista de acesso que possa aliar e identificar seu produto atingindo assim, todas as expectativas de uma campanha de sucesso? Isso não foi muito difícil para o estrategista Nizan Guanaes, que durante 0 governo de Fernando Henrique Cardoso (1994 a 2002), conseguiu destacar seu candidato como "Pai do Plano 
Real". Em 1994 Fernando Henrique Cardoso (PSDB) venceu as eleições no primeiro turno, com $54,27 \%$ dos votos contra $27,4 \%$ obtidos por Lula.

"A campanha de Fernando Henrique em 1988, contou com um orçamento de 42 milhões de dólares", fortalecendo assim, a indústria do marketing político no Brasil (Barel, 2007). O slogan da reeleição de FHC era: "Quem derrubou a inflação vai acabar com o desemprego". A coordenação de marketing da campanha usa como apelo midiático o momento de transformação econômica que o Brasil estava passando. Todos os textos veiculados usavam a questão da retomada do poder de compra, melhoria da economia e queda da inflação (cujo fantasma assustava 0 país), através das estratégias econômicas do Plano Real.

Diante da inovação proporcionada pela internet, o marketing político e a propaganda eleitoral tiveram que se adaptar para enfrentar um desafio: como veicular informações de cunho eleitoreiro para um público de forma inovadora e que gere interesse? O grande "mote" foi formatar um texto ou informação curta, imagética, inventiva, leve e de formato novo.

A mudança do formato do marketing político e da propaganda eleitoral brasileira se amplia com a campanha de Luiz Inácio Lula da Silva, que após três derrotas consecutivas, foi eleito presidente da República para o período de 2003 a 2006 e reeleito para o segundo mandato, de 2007 a 2010. Nesta campanha, além do carisma pessoal do candidato nas aparições públicas, o grande diferencial foi 0 trabalho massivo nas redes sociais, da militância em prol do candidato a presidência.

Nesta eleição Lula vence as eleições presidenciais, concorrendo com José Serra (PSDB/PMDB). No primeiro turno, Lula teve $46,44 \%$ dos votos contra $23,19 \%$ de Serra. No segundo turno, Lula garantiu a vitória com $61,27 \%$ dos votos. 0 responsável por essa transformação foi o estrategista Duda Mendonça que alavancou com sucesso a vitória do Partido dos Trabalhadores no Brasil. Ele foi responsável, em 2002, pelo marketing do governo até o escândalo do mensalão em 2005. Lula concluiu seu mandato com $87 \%$ de aprovação, tornando-se um dos mais populares presidentes da história do Brasil e um dos políticos mais respeitados do mundo. Foi também durante a sua gestão que o Brasil conquistou a sétima posição na economia mundial. O PT substitui 'paz e amor' por 'mudança social' (In: Folha de São Paulo, 03 de janeiro de 2003).

Apoiado em um marketing político de linha popular, com o uso de peças publicitárias com formato simples, com veiculação quase que diárias das ações do governo, Lula desenvolve um governo de grande aceitação popular e investe em programas sociais e dar acesso ao crédito às classes menos favorecidas. Comparando ano de 2002 com os anteriores (1989, 1994, 1998 e 2002), notou-se um grande avanço na imagem do presidente Lula do PT, principalmente, no que se refere às mudanças com investimento na aparência física, no peso corporal, nas roupas, na barba e no cabelo. 
Com base em dados da pesquisa de Porto (2002), pode-se detalhar a estratégia políica e comunicacional adotada pelo PT. De acordo com o autor, a campanha centrou em situações e problemas de grande apelo social, motivo de preocupação para a grande maioria dos brasileiros. Em sua análise: "(...) Lula dedicou 28,2\% do tempo total ao tratamento de análise da conjuntura. 0 apelo prioritário de sua campanha na TV foi o diagnóstico dos problemas do país, sendo o programa que mais dedicou tempo a essa temática. A atenção às políticas futuras a serem desenvolvidas ficou em segundo lugar com $18,4 \%$ do tempo. Desse modo, Lula associou a avaliação da $6^{\text {a }}$ situação brasileira à apresentação de soluções para os problemas e de propostas de seu governo. Cabe destacar o tom light da campanha do PT. Nesse caso, dois números trazidos por Mauro Porto são expressivos: Lula foi o candidato que mais dedicou tempo às músicas e jingles $(10,6 \%)$ e 0 que menos utilizou o recurso da propaganda negativa (2,5\%)." No comando do marketing político entra em cena o brasileiro João Santana, que foi responsável pela reeleição de Luiz Inácio Lula da Silva, em 2006, e pela eleição de Dilma Rousseff, em 2010, que foi ministra de Minas e Energia e depois ministra da Casa Civil durante seus dois mandatos. Ela venceu as eleições e se tornou a primeira mulher eleita presidente do Brasil.

Dilma Rousseff venceu as eleições presidenciais de 2010, no segundo turno, com $56,05 \%$ dos votos válidos (derrotou o candidato José Serra, que obteve $43,95 \%$ dos votos válidos), tornando-se a primeira mulher eleita a presidência da República Federativa do Brasil. Ao tomar posse, no dia $1^{\circ}$ de janeiro de 2011, discursando no Congresso Nacional, Dilma afirmou: "Meu compromisso supremo [...] é honrar as mulheres, proteger os mais frágeis e governar para todos! [...] A luta mais obstinada do meu governo será pela erradicação da pobreza extrema e a criação de oportunidades para todos".

Representando um governo de coalizão e com apoio de vários partidos aliados, o governo Dilma começa a perder terreno. As alianças políticas se fragilizam frente ao arrocho econômico e o medo do fantasma da inflação. 0 que antes representava uma história de sucesso, que era 0 acesso aos bens e serviços, antes reservados aos setores da classe alta e média da população brasileira, passa a representar uma decepção. A população assiste com apreensão o projeto de governo com ênfase nas causas sociais ruir juntamente com seu sonho de estabilidade econômica.

Contrariando os otimistas, em Junho (2012), a gestão da presidente Dilma Rousseff entra em colapso. Desde o movimento "Fora Collor" a sociedade brasileira mantinha-se calada. A queda da popularidade de Dilma Roussef torna-se evidente com grandes revoltas em São Paulo, causadas pelo aumento dos preços das passagens de ônibus em São Paulo, o estopim para que manifestantes de todo o país fossem as ruas. Embora o movimento tenha começado com esse pretexto, manifestantes de todo o país utilizaram as mídias sociais, onde grupos diversos 
dispersavam tipos de solicitações ao governo sem que houvesse foco definido, pois a grande dificuldade localizar o verdadeiro líder desse movimento.

O desfecho chega ao seu final no dia 31 de agosto de 2016. A voz dos partidários e estrategistas da equipe política pouco pode fazer na cena política, de uma presidente eleita, mas sem a maioria na Câmara de Deputados. Sem sucesso assiste a derrocada de seu governo, com forte perfil midiático sem interlocução com os jornais, revistas e canais de TV que integram a linha da oposição. Qualquer que seja sua decisão, atualmente, torna-se cada vez mais distante às possibilidades da agora presidenta afastada, Dilma Rousseff volta a reintegrar-se com partidos, coalizões, para buscar alternativas políticas, pois a exposição da Operação Lava-Jato deflagrou uma onda de delação "premiada", de antigos companheiros e aliados e se assiste a perda de poder de alguns dos maiores políticos do país.

Nessa fase anticorrupção até seu principal aliado, Luís Inácio Lula da Silva está sob à mira dos órgãos da justiça e da polícia, e perde ao enfrentar as malhas da justiça do Brasil, agora sob a presidência de Michel Temer (também acusado de cometer ilícitos) que administra o país como se tivesse a "espada de Dâmocles" sobre sua cabeça, enfrentando problemas na famosa governabilidade. Como revitalizar a imagem do Presidente Temer de prestígio e pro-atividade diante do eleitor? Como salvaguardar o trabalho político do Presidente Temer até o final de seu mandato? Como conquistar aliados e reconstruir a imagem de Temer frente a opinião pública rechaçada e assoberbada de problemas financeiros gerados pela crise econômica por que passa o país?

Existe um trabalho enorme a ser feito. Este é o papel dos articulistas do marketing político e do staff da propaganda institucional do governo que sofreram profundos desgastes frente a onda de escândalos de corrupção envolvendo políticos de partidos da base do governo petista e, principalmente, o próprio PT, nos casos de corrupção passiva e ativa e de malversação do fundos e das contas públicas.

O quadro atual mostra-nos que o marketing político e a propaganda poderiam recuperar a imagem do presidente, tendo em vista a aceitação inicial, da sua proposta de governo centrado em iniciativas de recuperação da economia do país. $O$ foco do trabalho seria sua atuação e a imagem de eficiência profissional atualmente bastante prejudicada. Mas esse trabalho não pode ocorrer sem a concomitância de outra necessidade urgente: a reforma política e tributária, a questão da previdência social, motivo de preocupação para a busca de uma gestão eficiente e de resultados.

Kotler (1978, p. 20) coloca que assim seria sustentado pela relação de trocas voluntárias de valores por mercadorias, já Tomazeli (1988) diz que quando uma pessoa vende uma ideia de eficiência profissional, capacidade gerencial ou visão política propõe uma troca com um determinado público, esperando receber a aceitação, emprego ou cargo eletivo. Esta aceitação, no caso da política partidária, 
se dá na forma de votos que o candidato recebe em troca de suas promessas de atuação futura como político (Tomazeli, 1988, P.15).

Especialistas como Mancini \& Swanson (1996, p. 20-24) apontam fatores do contexto nacional que serão cruciais (deverão ser modernizados) para o sucesso das campanhas políticas nesse mercado atual competitivo. Resumidamente temos na realidade brasileira os seguintes determinantes:

\begin{tabular}{|c|c|}
\hline Os sistemas & Fatores determinantes \\
\hline $\begin{array}{c}\text { 1: Sistema } \\
\text { Eleitoral }\end{array}$ & $\begin{array}{l}\text { O sistema majoritário favorável à personalização das } \\
\text { campanhas do que o sistema proporcional com lista } \\
\text { fechada, que confere maior força aos partidos. (..) em torno } \\
\text { da disputa pelo Executivo; essa disputa, absolutamente } \\
\text { personalista, atua portanto como força estruturante sobre } \\
\text { aquela, nas esferas municipais, estaduais e federal; }\end{array}$ \\
\hline $\begin{array}{l}\text { 2: Sistema } \\
\text { Partidário }\end{array}$ & $\begin{array}{l}\text { Embora a modernização chegue igualmente a sistemas bi e } \\
\text { multipartidários, ela dá-se com rapidez maior nos primeiros, } \\
\text { (...) no Brasil, o sistema multipartidário consolidado em } 1985 \\
\text { incentivou o surgimento e o fortalecimento de agremiações } \\
\text { de fortes como PT, Partido Comunista do Brasil (PCdoB) e } \\
\text { Partido Socialista dos Trabalhadores Unificado (PSTU); isso } \\
\text { fez que a modernização chegasse mais lentamente ao } \\
\text { sistema partidário nacional; }\end{array}$ \\
\hline $\begin{array}{l}\text { 3: Regula- } \\
\text { mentação }\end{array}$ & $\begin{array}{l}\text { (...) Sendo mais rígida a regulamentação das campanhas, } \\
\text { mais restritas mostram-se as possibilidades de adequação } \\
\text { local do modelo modernizado; neste sentido, adquirem } \\
\text { maior importância as leis que versam sobre o uso dos } \\
\text { meios eletrônicos e o financiamento das campanhas; }\end{array}$ \\
\hline $\begin{array}{l}\text { 4: Cultura } \\
\text { Política }\end{array}$ & $\begin{array}{l}\text { (...) temos que, as práticas de campanha se moldam a cada } \\
\text { cultura política nacional, principalmente no que toca a } \\
\text { aspectos como socialização política, participação cívica, } \\
\text { estruturas de agregação social, efetividade dos canais de } \\
\text { comunicação interpessoais e importância dos grupos } \\
\text { societais primários e secundários. (...) no seio das famílias } \\
\text { tradicionais mostram-se bem menos receptivas ao modelo } \\
\text { modernizado do que as sociedades em que a fragmentação } \\
\text { enfraqueceu as estruturas tradicionais de socialização, } \\
\text { informação e participação políticas; }\end{array}$ \\
\hline $\begin{array}{l}\text { 5: Sistema dos } \\
\text { meios de massa }\end{array}$ & $\begin{array}{l}\text { (...) temos os sistemas midiáticos nacionais avançados } \\
\text { tecnologicamente, como a televisão atinge quase a } \\
\text { totalidade dos indivíduos como fonte por vezes única de } \\
\text { informação e de entretenimento tem favorecido a } \\
\text { modernização das campanhas eleitorais; ao contrário, os } \\
\text { sistemas em que grande parte da população não tem acesso } \\
\text { aos aparelhos e/ou as transmissões não cobrem parcelas }\end{array}$ \\
\hline
\end{tabular}




\begin{tabular}{|l|l|}
\hline & significativas do território, constituem-se em um óbice à \\
modernização. (...) No Brasil, as novas feições das \\
campanhas eleitorais inserem-se em uma estrutura que \\
constrange, limita e incentiva: a "sociedade midiática".
\end{tabular}

Fonte: Mancini \& Swanson (1996, p. 20-24) adaptada a pesquisa.

\section{3.-Metodologia.}

A pesquisa se utilizou do método qualitativo, com base a pesquisa bibliográfica, realizada com autores expertos do jornalismo, da propaganda e do marketing político, com contribuições relevantes, de cunho exploratório, sobre as principais ideias, conceitos, planejamento e estratégias voltadas para campanhas de sucesso.

Numa proposta de estudo do tipo descritivo e analítico, uma vez que se utilizou de análises bibliográficas e documentais, bem como, depoimentos de autores consagrados exemplificando e analisando situações para uma melhor compreensão sobre o fenômeno político e eleitoral entre candidatos e eleitores. Estudos sobre o marketing político e a propaganda eleitoral no Brasil é uma fonte de informação que contribui no entendimento das etapas significativas de uma comunicação especializada.

Este artigo traz à luz do marketing político e os relevantes aspectos do marketing político e da propaganda, evidenciando pontos positivos e negativos de campanhas eleitorais bem sucedidas, tecendo críticas e comentários sobre os desdobramentos do trabalho com essa vertente em comunicação.

\section{4.-Discussão dos resultados.}

O artigo em si se propôs a uma reflexão acerca da evolução e do trabalho com 0 marketing político eleitoral e da propaganda eleitoral e política no Brasil.

O estudo bibliográfico abordou o marketing político e alguns exemplos de campanhas de sucesso, as estratégias instrumentais da propaganda nos permitiu analisar 0 desenvolvimento tecnológico, a influência fundamental para a diversificação das formas de comunicação política. 0 fenômeno internet a qual provocou uma alteração nas formas de veiculação, ampliando o alcance do trabalho como a do marketing político. Uma das mudanças, à ampliação das formas de relacionamento entre políticos e eleitores, bem como as formas de construção da imagem do político e do trabalho do marketing conforme tabela explicativa abaixo:

\begin{tabular}{|l|l|}
\hline Governos & Marketing \\
\hline $\begin{array}{l}\text { Getúlio Vargas } \\
1937-1945\end{array}$ & O pai dos pobres, adquiriu um caráter mítico de líder nacional. \\
\hline Juscelino & Um homem popular, carismático, exímio articulador e muito \\
\hline
\end{tabular}


Revista Internacional de Apoyo a la Inclusión, Logopedia, Sociedad y Multiculturalidad. Volumen 4, Número 1, Enero 2018, ISSN: 2387-0907, Dep. Legal: J-67-2015 http://riai.jimdo.com/

\begin{tabular}{|c|c|}
\hline $\begin{array}{l}\text { Kubitschek } \\
1956-1961\end{array}$ & Bem assessorado em termos profissionais. \\
\hline $\begin{array}{l}\text { Jânio Quadros } \\
1961 \text {-1964 }\end{array}$ & Soube falar diretamente ao coração dos eleitores \\
\hline $\begin{array}{l}\text { Regime militar } \\
\text { 1964-1985 }\end{array}$ & Usaram muito a mídia para difundir as suas ideologias \\
\hline $\begin{array}{l}\text { José Sarney } \\
1985-1990\end{array}$ & $\begin{array}{l}\text { Ordem democrática: Enfrentou dificuldades devido ao grande } \\
\text { arrocho econômico, inflação em alta, diminuiu o poder de } \\
\text { compra da população, gerando grande descontentamento na } \\
\text { classe média com popularidade em baixa, }\end{array}$ \\
\hline $\begin{array}{l}\text { Fernando Collor } \\
\text { 1991-1993 }\end{array}$ & $\begin{array}{l}\text { O “caçador de marajás". } \\
\text { 'Impeacheament' }\end{array}$ \\
\hline $\begin{array}{l}\text { Fernando } \mathrm{H} . \\
\text { Cardoso } \\
1994-2002 \\
\end{array}$ & $\begin{array}{l}\text { Indústria de Marketing } \\
\text { "Pai do Plano Real". } \\
\text { "Quem derrubou a inflação vai acabar com o desemprego". }\end{array}$ \\
\hline $\begin{array}{l}\text { Luiz Inácio Lula } \\
\text { da Silva } \\
2007-2010 \\
2011-2014\end{array}$ & $\begin{array}{l}\text { O novo formato de marketing político e da propaganda } \\
\text { eleitoral. } \\
\text { O carisma pessoal do candidato nas aparições públicas, o } \\
\text { grande diferencial foi o trabalho massivo nas redes sociais e } \\
\text { da militância em prol do candidato à presidência. } \\
\text { O marketing de linha popular, com o uso de peças } \\
\text { publicitárias com formato simples. }\end{array}$ \\
\hline $\begin{array}{l}\text { Dilma Roussef } \\
\text { 2015-2016 }\end{array}$ & $\begin{array}{l}\text { O perfil midiático } \\
\text { Compromisso supremo [...] honrar as mulheres, proteger os } \\
\text { mais frágeis e governar para todos! Ênfase na erradicação da } \\
\text { pobreza extrema e a criação de oportunidades para todos". }\end{array}$ \\
\hline $\begin{array}{l}\text { Michel Temer } \\
2017 . . .\end{array}$ & $\begin{array}{l}\text { Assume também acusado de cometer ilícitos. Administra o } \\
\text { país como se tivesse a "espada de Dâmocles" sobre sua } \\
\text { cabeça, enfrentando problemas na famosa governabilidade, } \\
\text { ênfase na retomada da economia. }\end{array}$ \\
\hline
\end{tabular}

Fonte: A própria pesquisa.

No entanto, o sensacionalismo vem ditando a moda. A exposição desenfreada em mídias sociais vem mudando o trabalho do marketing político e eleitoral. Isso, pela permanente exposição modificou o perfil do eleitor. Atualmente "As campanhas eleitorais foram modernizadas desenvolvem-se tendo como pano de fundo sociedades espetacularizadas ou até mesmo estados espetacularizados (Schwartzenberg, 1978; Debord,1997). Em determinadas situações podem ser construídas ou destruídas carreira de sucesso num estalar de dedos. 0 exemplo acima revela o novo perfil da sociedade mais comunicativa e global.

$\mathrm{Na}$ sociedade midiática as imagens transmitidas pelos veículos, entre eles a televisão, imprimem um caráter de autoridade e, ao mesmo tempo, incutem nos indivíduos- os telespectadores uma realidade "sólida", compacta. Nesse sentido, os telespectadores não buscam interpretar tendo por base as imagens, ou a partir dos 
elementos não postos explicitamente, fazendo com que o elemento visual sobreponha-se ao uso do intelecto, do raciocínio.

O tempo pós-moderno e midiático aponta caminhos e impõe desafios ao trabalho com o marketing político e eleitoral e surge a grande questão: Numa sociedade voltada para uma democracia massiva, há modos mais eficientes para se realizar campanhas eleitorais? Urge uma análise histórica da sociedade em que vivemos: midiática, imediatista, globalizada e em constante transformação.

O caminho parece apontar para formas diferentes e criativas, com outras estruturas comunicacionais para o convencimento dos eleitores. A diversificação das formas de acesso ao eleitor, mas sem perder de vista o veículo que tem o maior poder de entrar nos lares- de forma realmente democrática- que é a televisão.

Um dos trabalhos fundamentais para um bom marketing político e eleitoral com vistas a uma campanha é a pesquisa de campo. De acordo com Mendonça (2001) é uma técnica indispensável, principal fonte de informação no início e durante a campanha. A sondagem popular- que pode ter uma abordagem quantitativa (ênfase nas preferências e aspirações, desejos de eleitores ou de um grupo de eleitores); ou uma abordagem qualitativa, que procura conhecer o pensamento, como se comportará determinado grupo ou camada de uma população.

Os marqueteiros não podem esquecer-se de reavaliar seu trabalho, assumindo os erros no feedback após às ações ligadas aos marketing e a propaganda. Esse exercício é importante e está diretamente ligado a celeridade com que os papéis se invertem e do quanto o público, o telespectador pode mudar de opinião, ser volatizado na sua escolha pela rapidez com que informações novas chegam através de outras mídias- essas interativas como as redes sociais. Para consolidar uma visão otimista e dá credibilidade ao trabalho no marketing durante as campanhas políticas o ideal é o uso da linguagem jornalística, séria, sem apelações.

Nesse sentido o autor observa a questão da emoção e defende que a propaganda tem que chamar atenção. Então, para Mendonça (2001) o marqueteiro tem que usar técnicas seguras voltadas para criar expectativa e "emocionar", o marqueteiro pode sofrer riscos na sua comunicação política. Por isso, se torna importante a linguagem jornalística no marketing de campanha eleitoral porque os critérios de objetividade, de racionalidade não podem ser deixados de lado, frente a uma campanha cujo resultado positivo será a implantação de governos e de políticos nas esferas legislativa e executiva do país.

\section{5.-Conclusão.}

Sob este contexto, firma-se a necessidade de construção de novas estruturas profissionais mais centradas, eficientes e ágeis para enfrentar as campanhas eleitorais competitivas e altamente dispendiosas para candidatos e partidos de grande poder aquisitivo. Para vencer esse mundo altamente competitivo e midiático 
o profissional tem que se imbuir de criatividade, dinamismo, pesquisa eficaz sobre seu público para vencer barreiras, obstáculos que podem pulverizar campanhas, onde o farto poder aquisitivo não é a tônica, mas sim as ideias e a vontade de participar do exercício político e dos processos democráticos do país.

Outra questão fundamental para um bom trabalho em marketing político e eleitoras é primar pela lisura nas doações financeiras. A história recente do Brasil, onde as operações da Lava-Jato descobriu uma rede de corruptos e corruptores, na sua grande maioria, com práticas ilícitas em doações para campanha, se torna cada vez mais necessário o exercício da ética profissional. Observa-se uma mudança no aparato e na ação do poder judiciário. Mas, a frouxidão da legislação eleitoral no tocante a doadores jurídicos constitui sério entrave à autonomia do campo da política frente aos interesses financeiros econômicos.

Percebeu-se ainda, numerosos vícios no trabalho, muitos ligados ao mascaramento da realidade integrando-os com as estratégias massivas do marketing político. Suas estratégias, em longo prazo e a própria disputa no campo eleitoral, tiveram uma convergência na propaganda institucional e eleitoral.

Por outro lado, vimos uma população às vezes desinteressada que, desassistida, na grande maioria dos casos, e que ainda não tem capacidade de interpretar fatos, por falta de uma cultura política. A falta de cultura política está diretamente ligada às dificuldades de acesso à informação que ainda persiste no Brasil, país de proporções continentais. Nesse contexto gera-se um círculo vicioso: por falta de conhecimento e informação falha 0 eleitor ao questionar a política pública e dos gestores, aos seus malfadados projetos e, nem tampouco acompanham os mandatos dos eleitos e falha os políticos eleitos porque não conhecem verdadeiramente seus eleitores- que deveriam legitimamente representados.

E qual é o cenário atual? 0 cenário mostra-nos uma descaracterização da função e do trabalho político. 0 espaço de diálogo entre políticos e cidadãos encontra-se contaminado pelas injunções, conchavos e acordos velados em detrimento das necessidades emergenciais da população que começam a rejeitar as atitudes da "velha política" do oportunismo e clientelismo.

Essa visão paradigmática é realidade mudança de um paradigma newtoniano, cartesiano, dogmático e tradicional, para um paradigma relativista, einsteiniano, que não modela, que não enquadra, que relativiza as formas de agir, de pensar numa dinâmica mais aberta, que respeite o movimento constante da sociedade em mudança. Muda-se a sociedade e as pessoas, e vice-versa. Nesse nível, o papel do marketing político e eleitoral tem que acompanhas esses movimentos de transformação, observar de onde aparecem as demandas, sem perder de vista 0 individual- que são as pessoas, em sua constante luta por um espaço nesse mundo de trabalho competitivo.

Contudo, é fundamental fortalecer a relação entre o marketing político e a eleitoral com a sociedade civil, que está aí, com sua realidade-mundo, com suas 
contradições e com mudanças que se impõem frente a realidade local- comunitária. Mas, a comunidade existe, e o trabalho de marketing não pode prescindir dessa relação.

Somente a partir dessa mudança teríamos um trabalho de marketing político e propaganda eleitoral, realmente, de candidatos afinados com o povo, que, ao serem eleitos, atuariam como representantes legítimos dos interesses coletivos, para o fortalecimento da gestão pública, a favor de uma sociedade equânime, de acordo com o ideal democrático. A união entre os interesses individuais e os interesses coletivos apresenta-se como um caminho de mudança. Somente aproveitando as zonas de contato entre a comunidade e a sociedade como um todo- o profissional do marketing tem uma posição de estabilidade para traçar as suas estratégias de atuação, principalmente durante a fase de planejamento de uma campanha política e eleitoral.

\section{6.-Referências.}

Amaral, K. (2006). Getúlio Vargas: a propaganda ideológica da construção do líder e do mito. IN: Queiroz, Adolpho (org.). Na arena do marketing político. São Paulo: Summus.

Barel, M.S. (2007). O marketing eleitoral e a ABCOP: história e profissionalização da comunicação política no Brasil. Conferência Brasileira de Comunicação e Marketing Político. Santa Bárbara d'Oeste, Paraná: VI Politicom. v.8., n.9., p.10.

Beranger, J. (2006). Fernando Henrique Cardoso: as armas da educação na propaganda política. In: Queiroz, Adolpho (org.). Na arena do marketing político. São Paulo: Summus.

Gross, B.L., Newman, B.I., Sheth, J.N. (1991). Consumption Valves and Market Choices. Theory and Aplication. London: Cincinnatti.

Grossi, E. (2006). Jânio Quadros: as representações metafóricas da vassoura no imaginário popular. In: Queiroz, Adolpho (org.) Na arena do marketing político. São Paulo: Summus.

Kotler, P. (1978). Marketing: edição completa. II Tradução de: Marketing Management: analysis, planning and control. São Paulo: Atlas.

Kuntz, R.A., Luyten, J.M. (1982). Marketing político: a eficiência a serviço do candidato. São Paulo: Global.

Mancini, P., Swanson, D.L. (1996). Politics, Media and Modern Democracy: An International Study of Innovations in Electoral Campaigning and Their Consequences. London: Praeger. 
Marttiello, M.F.S., Ribeiro, A. (2006). A importância do marketing político e eleitoral no processo decisório do voto. Recuperado de: Issuu.com/.../docs/52310819-a-importancia-do-marketing-politico-eeleitoral.

Mendonça, D. (2001). Casos \& coisas. São Paulo: Globo.

Porto, M. A campanha de 2002, na Rede Globo. Televisão e eleições presidenciais. São Paulo: Globo.

Romanini, M.G. (2006). Prudente de Moraes a visão singular como sustentáculo do fenômeno coletivo. Recuperado de: http://www.portaleducacao.com.br/educacao/artigos/48963/marketing.pdf.

Rubim, A.A.C. (2012). Cultura e Política na Eleição de 2002: as estratégias de Lula Presidente. Recuperado de: www.plataformademocratica.org/Publicaçoes/16885-Cached.pdf.

Santa, R. (2001). Batalhas eleitorais 25 anos de marketing político. São Paulo: Geração.

Schwartzenberg, R.G. (1978). O Estado espetáculo. São Paulo: Círculo do Livro.

Silva, C.E. (2002). O Marketing eleitoral. São Paulo: Publifolha.

Teixeira, D. (2006). Marketing Político e eleitoral: uma proposta com ética e eficiência. Osasco, São Paulo: Novo Século.

Tomazeli, L.C. (1988). Marketing político. 2 ed. Porto Alegre: Mercado Aberto. 